\section{For Here or To Go? Purchasing Power Parity and the Big Mac'}

\section{Michael R. Pakko and Patricia S. Pollard}

 he theory of Purchasing Power Parity (PPP) has a long and venerable tradition in international economics.

Fundamentally, the theory states that prices of identical goods in different countries should be equal after adjusting for the rate of exchange between currencies. As a theoretical proposition, PPP serves as a solid foundation for thinking about the conditions under which prices in international markets adjust to attain long-term equilibrium. As an empirical matter, however, PPP has been a more elusive concept. ${ }^{2}$

The Economist has established another, though somewhat more recent, tradition: the Big M ac standard. Since 1986, The Economist has published yearly tongue-in-cheek comparisons of the prices of M CD onald's Big Mac sandwich in various countries around the world, evaluating prevailing exchange rates on the basis of these price differentials. A similar index has also been developed by the Union Bank of Switzerland in its annual comparison of prices and incomes around the globe. These lighthearted studies of international hamburger prices have predictably whet the appetites of the popular media and the financial press and have even given serious scholars food for thought. ${ }^{3}$

The attractive feature of the Big $\mathrm{M}$ ac as an indicator of PPP is its uniform composition. With few exceptions, the component ingredients of the Big M ac are the same everywhere around the globe. (See the shaded insert, "A Big Mac Is a Big Mac Is a Big Mac?") For that reason, the Big Mac serves as a convenient market basket of goods with which the purchasing power of different currencies can be compared.

Just as is the case with broader measures, however, the Big Mac standard fails to meet the demanding tests of PPP. In this article, we review the fundamental theory of PPP and describe some of the reasons why it might not be expected to hold as a practical matter. Throughout, we use the Big Mac data as an illustrative example. In the process, we also shed some light on the value of the Big M ac sandwich as a palatable measure of PPP.

\section{THE LAW OF ONE PRICE AND PURCHASING POWER PARITY}

A strong version of the purchasing power parity theory has as its foundation the law of one price. Abstracting from complicating factors such as transportation costs, taxes, and tariffs, the law of one price states that the price of any particular good that is traded on world markets will be the same price in every country engaged in trade.

For instance, consider the price of sesame seeds- one of the basic ingredients of the Big Mac-in Britain and the United States. Letting $p_{s s}^{f}$ and $p_{s s}^{\$}$ represent the prices of sesame seeds in Britain (in pounds) and the United States (in dollars), respectively, then the law of one price can be expressed as follows:

$$
p_{s s}^{f}=e \times p_{s s,}^{\$}
$$

where e is the pound/dollar exchange rate. If sesame seeds cost $\$ 6$ per bushel in the United States and the pound/dollar exchange rate is 0.5 , then the law of one price states that the price of sesame seeds in Britain should be $f 3$. If sesame seeds sold for a price higher than $£ 3$, an astute trader

\footnotetext{
${ }^{1}$ Big Mac is a registered trademark of McDonald's.

${ }^{2}$ Rogoff (1995) presents a thorough survey of recent research on PPP.

${ }^{3}$ As an example of the former, see Sapsford (1993); of the latter, see Cumby (1995).
} 


\section{A BIG MAC IS A BIG MAC IS A BIG MAC?}

At the close of 1995 it was possible to enjoy a Big Mac in more than 80 countries around the world. In each of these countries, the Big Mac is generally made according to the same recipe. However, there are some things that make a Big Mac unique to each country. First is the name itself. Though in most countries a Big Mac is known as a Big Mac, in China it is called a Juwuba, meaning "big with no equal," a reference to a popular Chinese Transformer toy hero. In Russia the Big Mac is known as a Beeg M ek Gamburger. (Since there is no equivalent of the letter $h$ in the Russian al phabet, all foreign words with $\mathrm{h}$ are pronounced as if the letter were a g.) In Japan it is a Biggu Macku.

In Israel the Big Mac is made with kosher meat, even though the inclusion of cheese in the recipe makes it a nonkosher sandwich. According to the M cDonald's franchiser in Israel, most Israel is prefer to eat kosher meat even when their meals are nonkosher. ${ }^{1}$ In Islamic countries, the menu is halal in accordance with Islamic law. The M CDonald's slated to open in India this year will not serve beef products in keeping with local practice. Thus the Big Mac is likely to be a vegetable or chicken burger.

Even when the sandwich tastes the same, the experience of eating a Big M ac in a foreign country may differ greatly from the typical U.S. experience. In Beijing and Moscow, eating a Big Mac is certainly not a solitary endeavor. Each city has a McDonald's with 700 seats and nearly 30 registers. Despite the grand scale in M oscow, a wait time of 40 to 45 minutes is still common. Patrons have been known to purchase Big Macs (and other McDonald's favorites) and resell them at a profit to those waiting in line. To limit this secondary market, customers are prohibited from purchasing more than 10 Big Macs per person.

MCD onald's has a policy of trying to get locally as many of its supplies as possible. In part, this is because of the import restrictions it faces. Thus, for example, although $M c D$ onald's claimed that the quality of the french fries produced by the local monopolist in Israel did not meet its standards, it was prohibited from importing french fries. So, McDonald's built its own french fry factory in Israel to supply its restaurants. In China M cDonald's developed a new potato strain because it was unable to find a good local substitute for I daho potatoes.

Though McDonald's generally relies on subcontractors to process much of the food it uses, in Russia it was forced to build its own processing plant to ensure the adequacy and quality of supplies for its restaurant. Moreover MCDonald's al so bought its own fleet of trucks to avoid the poor distribution system in Russia. With the breakdown of the Soviet system and increased privatization, M CD onal d's is now finding some local Russian businesses that can process some of its food items cheaper than it can while maintaining its quality standards. Thus, for example, it no longer processes cucumbers into pickles, but relies on a subcontractor to do this.

\footnotetext{
1 Curtius (1995).
}

could buy sesame seeds in the United States and sell them in Britain at a profit. This type of activity - known as arbitragewould tend to drive the price of sesame seeds higher in the United States and lower in Britain, with the process continuing until the law of one price prevailed.

\section{Absolute Purchasing Power Parity}

The law of one price generalizes to PPP under special circumstances. Consider price indexes (consumer price indexes, for example) for the United States and Britain, which are constructed by combining the prices of several different 
commodities. Typically, these indexes are weighted averages of the individual prices. If the same goods are included in each index and if the price indexes are constructed identically, then the overall price levels $P \$$ and $P{ }^{f}$ will be related in the same way as each of the individual commodities according to the law of one price:

$$
\mathrm{P} *=\mathrm{e} \times \mathrm{P} \$,
$$

where $\mathrm{P} *$ is the price level measured in the foreign currency and e is the exchange rate relative to the dollar (foreign currency units per dollar).

The conditions under which the law of one price generalizes to yield PPP-as summarized in equation 2-are clearly quite restrictive. In particular, because price indexes are weighted averages of individual prices, the law of one price will directly imply PPP only if the same goods are included and if the same weighting scheme is used to construct the indexes for different countries. Usually, these weights are based on actual consumption or production shares. So, for example, if more beef per capita is consumed in Britain and more pickles per capita are consumed in the United States, then the price of beef will be relatively more important in a British price index, whereas the price of pickles will be more important in a U.S. index. Even if beef and pickle prices are always identical in the two countries, a rise in the world price of beef will have a larger effect on the British price index than on the U.S. index.

Consequently, testing the absolute version of PPP requires careful construction of price indexes so that a common market basket of goods is measured. One example of such a comparison is embodied in the data set known as the Penn World Table (PWT), which is based on the United $N$ ations International Comparisons Program [see Summers and Heston (1991) ]. ${ }^{4}$ The PWT presents price measures that are based on a common market basket of approximately 150 detailed categories of goods.

The first column of Table 1 shows a measure of PPP for various countries (relative to the United States) based on data

\section{Table 1}

Indicators of Purchasing Power Parity (1991)

\begin{tabular}{l|c|c} 
& Penn World Table & Big Mac \\
\cline { 2 - 3 } Australia & 98 & 86 \\
Belgium & 113 & 129 \\
Britian & 110 & 132 \\
Canada & 104 & 90 \\
Denmark & 140 & 185 \\
France & 119 & 142 \\
Germany & 127 & 114 \\
Hong Kong & 75 & 51 \\
Ireland & 106 & 100 \\
Italy & 122 & 129 \\
Japan & 141 & 125 \\
Netherlands & 114 & 124 \\
Singapore & 91 & 70 \\
Spain & 108 & 150 \\
Sweden & 151 & 191 \\
& & \\
\hline
\end{tabular}

\section{Figure 1}

\section{PPP From the PWT and The Big Mac (1991)}

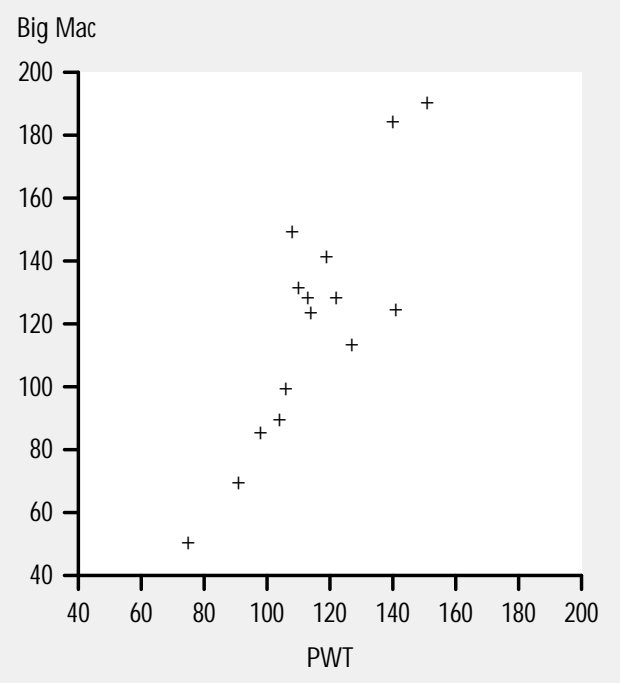

from the PWT for 1991. The PWT reports price data in dollars, $\mathrm{P} * / \mathrm{e}$, and from equation 2 we have $(1 / e) \times(P * / P \$)=1$. The figures reported in Table 1 are constructed as $[(1 / e) \times(P * / P \$)] \times 100$, so a value greater than 100 means that dollar-equivalent prices in the country under consideration are higher
${ }^{4}$ The data are drawn from a recent update of PWT, version 5.6 . 


\section{A NEW JINGLE?}

To aficionados of classic television commercials, the ingredients of a Big M ac sandwich are indelibly etched into memory in the form of a jingle. In terms of the United Nations' Standard International Trade Classifications (SITC), the jingle might sound a little different:

\begin{tabular}{|c|c|c|}
\hline Ingredient & SITC Code & SITC Description \\
\hline All-beef patties & 01122 & Meat of bovine animals, boneless, frozen \\
\hline Special sauce & 09849 & $\begin{array}{l}\text { Sauces and preparations, not elsewhere specified } \\
\text { (NES), mixed condiments, and seasonings }\end{array}$ \\
\hline Lettuce & 05454 & Lettuce and chicory, fresh or chilled \\
\hline Cheese & 02420 & Processed cheese, not grated or powdered \\
\hline Pickles & 05456 & Cucumbers and gherkins, fresh or chilled \\
\hline Onions & 05451 & Onions and shallots, fresh or chilled \\
\hline \multirow[t]{2}{*}{ Sesame-seed bun } & 04849 & Bakers' wares, NES \\
\hline & 22250 & Sesame (sesamum) seeds \\
\hline
\end{tabular}

${ }^{5}$ The terms overvalued and undervalued are used here in a strictly descriptive sense, not to imply that exchange rates are, in some sense, wrong.

${ }^{6}$ In his econometric study of PPP using the Big Mac price data, Cumby (1995) found statistical evidence that deviations from PPP are, in fact, temporary. Additionally, he found that the adjustment toward PPP tends to take place through local currency prices, rather than exchange rates. than prices in the United States. We can interpret this as the U.S. dollar having a lower purchasing power in that country relative to the United States or as the local currency being overvalued relative to the dollar. A value of less than 100 indicates that dollar-equivalent prices are lower than prices in the U nited States - the local currency is undervalued. ${ }^{5}$ Clearly, absolute PPP does not hold strictly for the currencies of countries reported in Table 1.

Another collection of commodities that is common across countries is the ingredients of the Big Mac sandwich. Sold in more than 80 countries around the world, the Big Mac is a standardized bundle of goods. M ost of the ingredients that go into a Big $M a c$ are individually traded on international markets, so we might expect that the law of one price would hold, at least approximately. (See the shaded insert, "A N ew Jingle?") The second column of Table 1 shows measures of PPP based on Big M ac prices. Note that a similar pattern emerges for the Big Mac measure as for the PWT measure of PPP. The correlation between these two price measures is 0.85 , and of the 15 countries shown in Table 1 there is only one country (Canada) for which the two price measures indicate differing quali- tative conclusions regarding overvaluation or undervaluation. The close relationship between PWT price indexes and Big M ac prices is illustrated graphically in Figure 1.

A total of 200 individual observations, collected over the 10-year period 1986-95, are available from The Economist Big M ac surveys. (PPP data for all of these observations are reported in Table A1 on p. 19). Among these observations only 6.5 percent show deviations of 5 percent or less from PPP, and only 15.5 percent of the observations show deviations of 10 percent or less. These statistics indicate that for most observations there are significant deviations from PPP. For example, the data indicate that in 1995 the yen was overvalued by 100 percent against the U.S. dollar, whereas the Swiss franc was overvalued by 125 percent against the dollar. In contrast, in 1995 the Chinese yuan was undervalued by 55 percent against the U.S. dollar and the Hong Kong dollar was undervalued by 47 percent relative to the U.S. dollar.

Figure 2 provides a graphical analysis of absolute PPP over time for selected countries, comparing actual exchange rates (relative to the U.S. dollar) with the ratio of countries' Big Mac prices relative to Big Mac prices in the United States. An overvalued currency is one for which the Big Mac price ratio ( $\mathrm{P} * / \mathrm{P} \$)$ exceeds the exchange rate (e).

Figure 2 demonstrates not only that departures from PPP are common, but also that for most currencies the direction of the deviation is maintained throughout the sample period. For example, the Australian dollar, the Hungarian forint, and the Hong Kong dollar have all been consistently undervalued, whereas the German mark, the Japanese yen, the South Korean won, and the Swedish krona have been consistently overvalued against the U.S. dollar.

Moreover, it is not obvious that there is a tendency for deviations from PPP to dampen over time. ${ }^{6}$ Two notable cases in which the deviations have persisted or increased are the Hong Kong dollar and the Hungarian forint. The Japanese yen showed some movement toward parity with the dollar from 1988 to 1990 but has 


\section{Figure 2}

\section{Absolute Purchasing Power Parity}

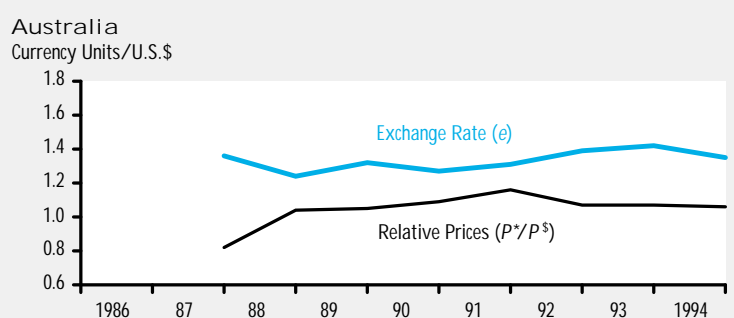

Germany

Currency Units/ U.S.\$

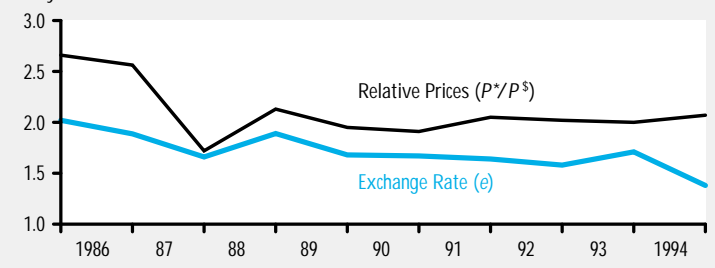

Hungary

Currency Units/ U.S.\$

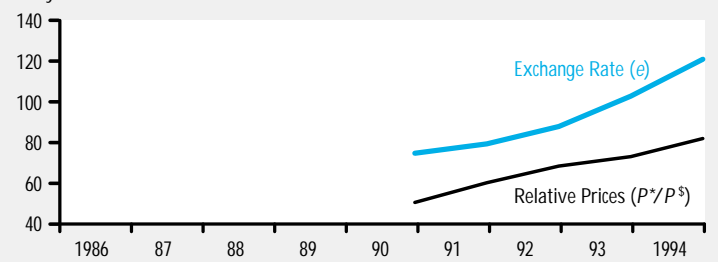

China

Currency Units/ U.S.\$

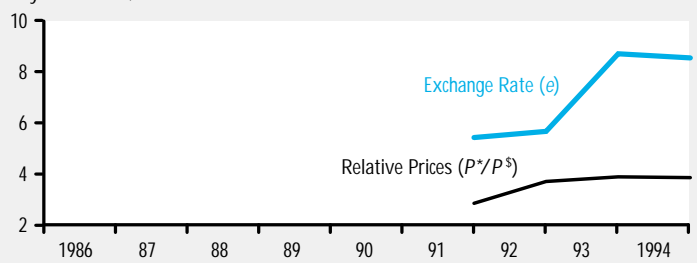

Japan

Currency Units/ U.S.\$

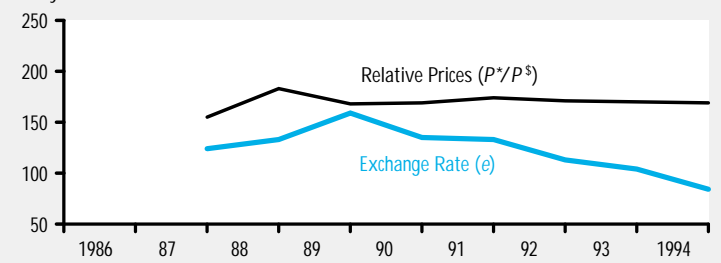

Russia

Currency Units/ U.S.\$

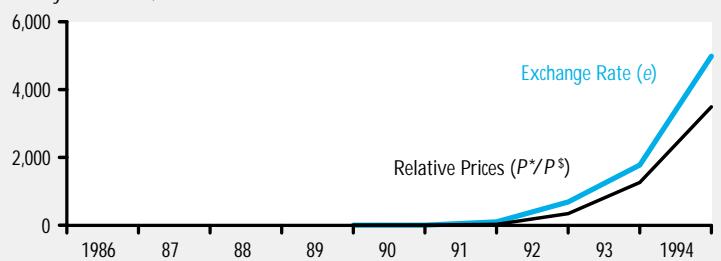

Canada

Currency Units/ U.S.\$

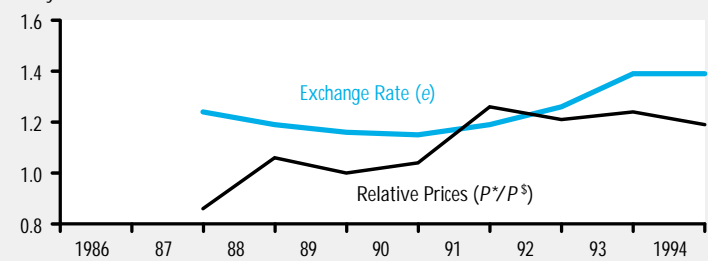

Hong Kong

Currency Units/ U.S.\$

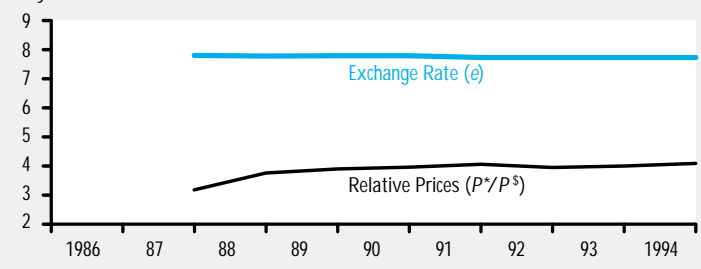

Ireland

Currency Units/ U.S.\$

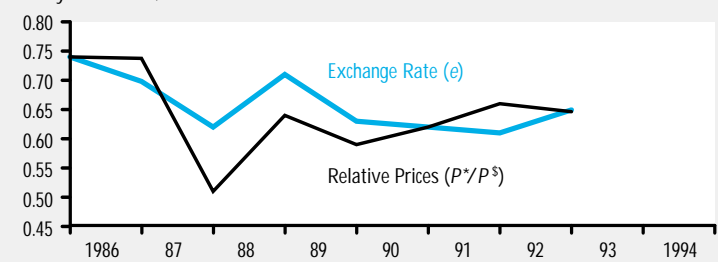

Britain

Currency Units/ U.S.\$

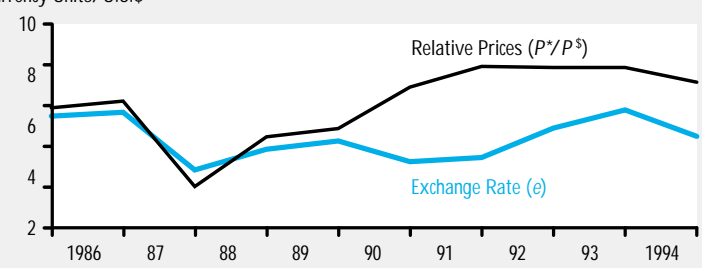

South Korea

Currency Units/ U.S.\$

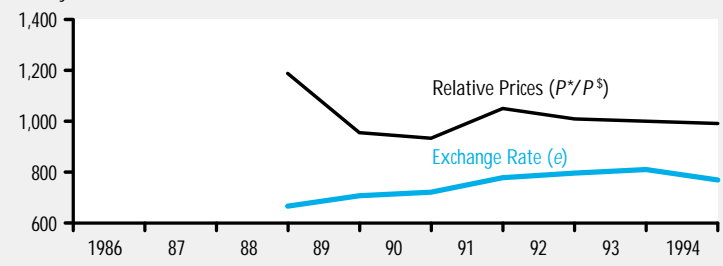

Sweden

Currency Units/ U.S.\$

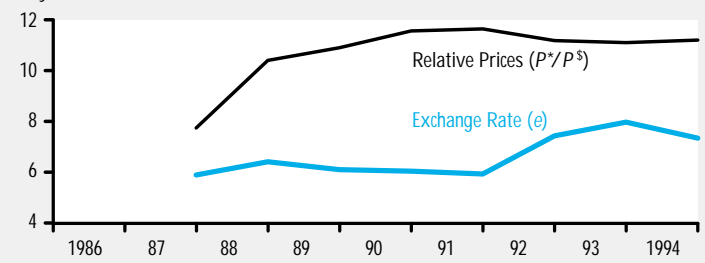




\section{Figure 3}

\section{Relative Purchasing Power Parity: Inflation Differential Less Exchange Rate Change Percent}

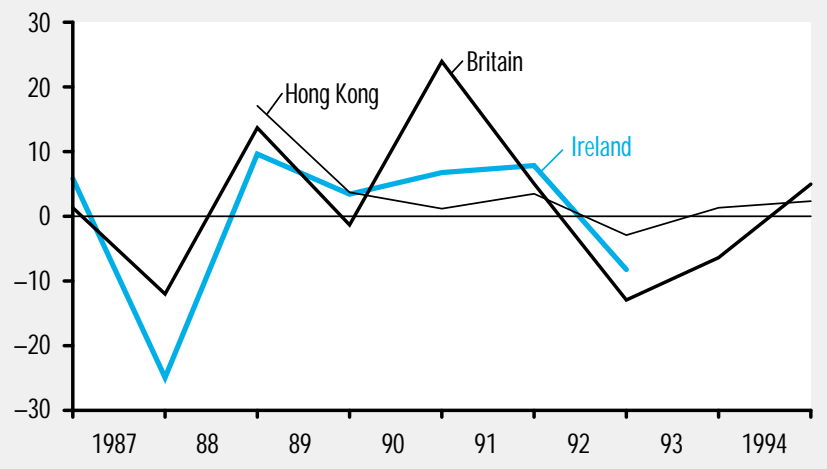

Percent

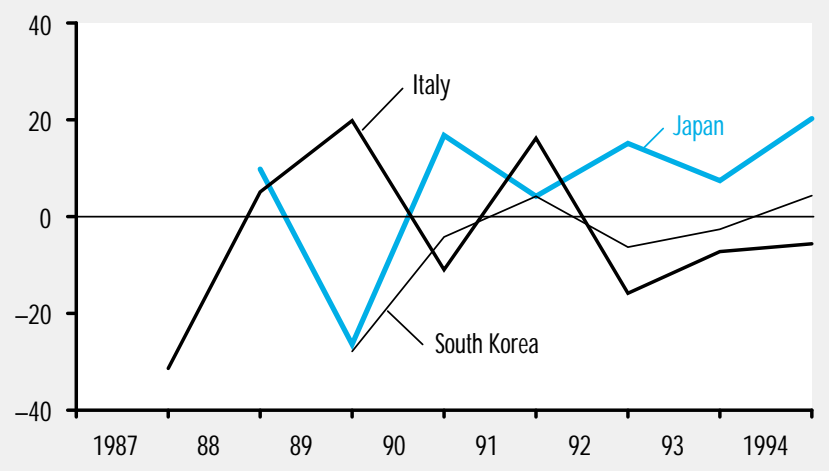

${ }^{7}$ Equation 3 is only an approximation of relative PPP. More appropriately, relative PPP can be expressed as $\Delta \ln (e)=$ $\Delta \ln \left(P^{*}\right)-\Delta \ln \left(P^{\$}\right)$. This formula and equation 3 will produce the same results for small percentage changes. The relative PPP data discussed here and reported in Table A2 on $\mathrm{p}$. 20 are calculated using log changes. moved further away from parity in each year since. The Irish punt is the one currency for which there is clear evidence of a continuing movement back to parity following deviations.

Throughout this article, we evaluate PPP relationships between foreign currencies and the U.S. dollar. Conceptually, however, the data presented in Table A1 ( $p .19)$ can be used to determine whether or not PPP holds between any two currencies. As an example, the shaded insert, "The Big Mac and the European Exchange Rate Mechanism," discusses PPP relationships using the German mark as the base currency.

\section{Relative PPP}

Given the difficulties with constructing appropriate market baskets for testing absolute PPP, a weaker version of the theory is often considered. This relative version of PPP states that changes in price levels will be related to changes in exchange rates. Specifically, equation 2 can be transformed to express a relationship in growth rates as follows?:

$$
\% \Delta \mathrm{e}=\% \Delta \mathrm{P} *_{-} \% \Delta \mathrm{P} \$ .
$$

Equation 3 says that the percentage change in the exchange rate between two countries is equal to the difference in their inflation rates. For example, if U.S. inflation is 5 percent a year while inflation in Britain is 3 percent a year, then the relative version of PPP states that the dollar will depreciate by 2 percent a year. Relative PPP is a less strict condition than absolute $P P P$, requiring only that deviations from PPP not worsen.

$M$ easures of relative PPP in relation to the U.S. dollar are presented in Table A2 (p. 20). These measures are summarized for the currencies of selected countries in Figure 3, which shows a measure of the difference between the Big Mac inflation differential ( $\left.\% \Delta \mathrm{P} *_{-} \% \Delta \mathrm{P} \$\right)$ and the change in the exchange rate $(\% \Delta \mathrm{e})$. We would not necessarily think that relative PPP would hold on a year-to-year basis, but is more likely to be observable in terms of an average relationship over many years. Consequently, relative PPP is suggested by the measures shown in Figure 3 whenever the spread between the inflation differential and the exchange rate change tends to center on zero, rather than to exhibit persistent deviations away from zero. For several countries, this appears to be the case. For example, the currencies of Hong Kong and South Korea both appear to have approximately maintained relative PPP against the dollar since 1991- despite the fact that absolute PPP clearly has not held for either of these currencies (see Figure 2). On the other hand, the Japanese yen has shown little evidence of maintaining even relative PPP against the dollar.

As a long-run test, relative PPP is somewhat difficult to evaluate for the Big $M$ ac because data are limited for many countries and there are only a few years of observations. The data suggest, however, 


\section{THE BIG MAC AND THE EUROPEAN EXCHANGE RATE MECHANISM}

The figure to the right presents PPP information for the currencies in the Exchange Rate Mechanism (ERM) of the European Monetary System relative to the German mark. The upper panel shows the PPP behavior of the currencies at the core of the ERM, and the lower panel considers the weaker currencies in the ERM. Once again, there are substantial persistent deviations from absolute PPP. In general, the core currencies have been overvalued relative to the mark. The Dutch guilder has been closest to parity over most of the sample period, and the Danish kroner has been the most overvalued of the four currencies. The 1995 PPP index numbers for the core currencies, with the exception of the Danish kroner, lie within the fluctuation bands permitted under the ERM.

\section{Purchasing Power Parity in the Exchange Rate Mechanism}

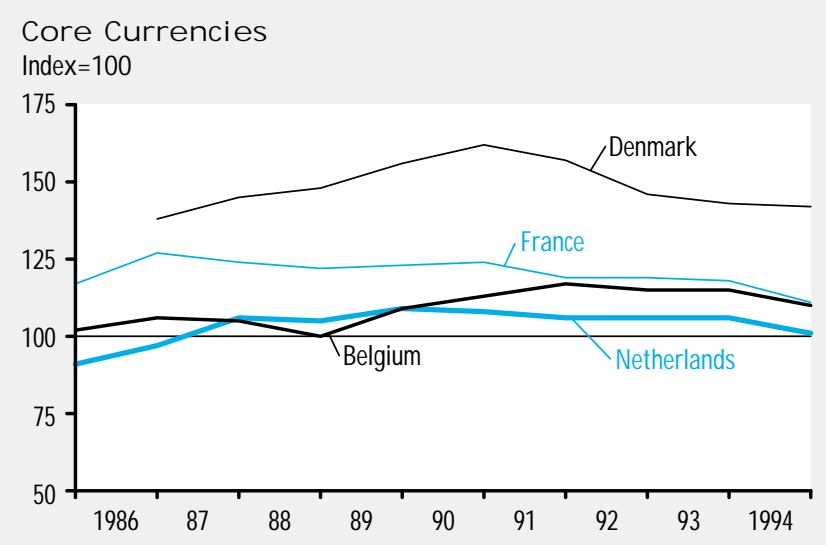

Weak Currencies Index $=100$

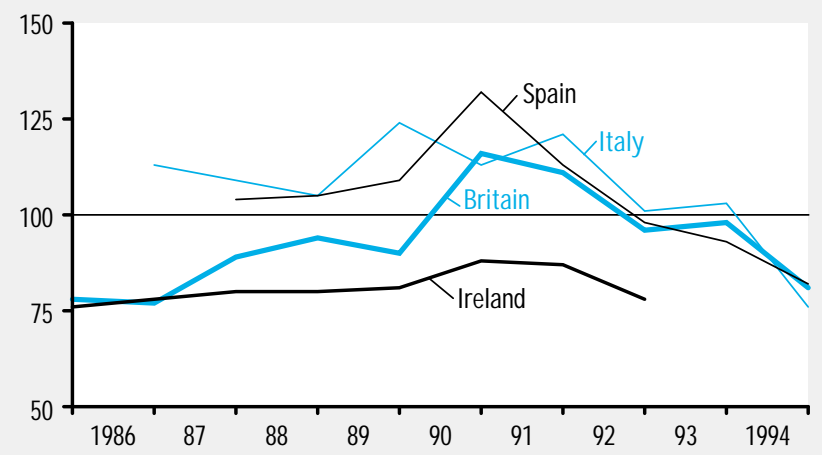

As one would expect, the core currencies have been closer to parity with the mark than the weak currencies (again with the exception of the Danish kroner). The lower panel shows that before its October 1990 entry into the ERM, the pound was undervalued against the mark. During the two years (1991-92) in the sample in which the pound was a member of the ERM, it was overvalued against the mark. However, initially following its September 1992 withdrawal from the ERM, the pound moved closer to parity with the mark. The Big Mac index thus lends support to those who have argued that the pound entered the ERM at too high an exchange rate (DM/f). The Spanish peseta (which entered the ERM in June 1989) and the Italian lira were also overvalued before 1993. Thus this figure provides some explanation as to why these currencies came under attack within the ERM. Even more striking is the sharp undervaluation of the pound, the lira, and the peseta that have occurred since 1992. All three currencies now are undervalued by nearly 20 percent or more against the mark.

Though PPP theory may explain some of the tension within the ERM that arose in 1992-93, it cannot explain why the Irish punt came under pressure because on a PPP basis the punt has been undervalued against the mark. This undervaluation was made worse by the 10 percent devaluation of the punt in February 1993. 
that PPP does not generally hold in the short run, for either the absolute or the relative versions of the theory (see Tables A 1 and A2). Furthermore, for many currencies, deviations from PPP against the U.S. dollar appear to be sustained over a period of several years. The next section provides some explanations for these deviations from PPP.

\section{WHY DOES PPP FAIL?}

In 1994 it cost $\$ 2.30$ to buy a Big Mac in the United States, $\$ 3.77$ to buy a Big $M a c$ in Japan, and $\$ 1.66$ to buy a Big M ac in Hungary. Thus a Big Mac devotee could buy nearly one and two-thirds of the sandwiches in the United States for every one he could purchase in Japan. He could buy less than three-quarters of a Big Mac in the United States for every one he could enjoy in Hungary.

However, one wouldn't expect Japanese and U.S. consumers to import Big Macs from Hungary to take advantage of the lower prices-a Big Mac sandwich shipped halfway across the globe would probably not arrive in a very appetizing form. Nevertheless, because the components of a Big Mac are traded on world markets, the law of one price suggests that prices of the components should be the same in all markets.

If the Big Mac is no more than the sum of its ingredients, then trade should equalize the price of a Big Mac across borders; or at the least, differences between prices should narrow over time. Instead, the dollar price of a Big M ac in the three countries diverged by even more in 1995 than in 1994. In 1995 it cost $\$ 1.58$ to buy a Big Mac in Hungary, $\$ 2.32$ to buy a Big $M a c$ in the United States, and $\$ 4.65$ to buy a Big M ac in Japan.

How do we explain these deviations from PPP? Once again, the Big M ac can serve as a useful example of why there tend to be systematic departures from PPP. We consider four main explanations: the existence of barriers to trade, the inclusion of non-traded elements in the cost of a Big Mac, imperfect competition, and the existence of current account imbalances.
Barriers to Trade

One simple reason why PPP, at least in the absolute sense, fails to hold is that it is costly to ship goods across countries. The cost of shipping the sesame seeds needed for the Big Mac buns may be minimal. Shipping perishable ingredients such as lettuce and beef is more costly. Transportation costs therefore may drive a wedge between the prices of the same good in different markets.

Suppose for example, that shipping costs add $\$ 0.10$ to the price of a Big M ac in Japan relative to the price in the United States. In this case, though economists would see as a violation of PPP a Big Mac costing $\$ 2.30$ in the United States and one costing $\$ 2.40$ in Japan, the difference in price would not result in a movement of Big M acs (or more appropriately the ingredients of Big Macs) from the United States to Japan. Only if the prices of the Big Macs in the two countries differed by more than $\$ 0.10$ would goods be shipped between the countries to take advantage of price differences. As a result, we might expect absolute PPP to hold only approximately, with prices diverging within a range determined by the transport costs. ${ }^{8}$

A more important factor than the presence of natural barriers to trade is the existence of tariffs and other legal restrictions on trade. N early every country restricts the importation of agricultural goods through the use of tariffs and quotas in order to protect its domestic farm sector. Tariffs, which represent a tax on imported goods, and quotas, which limit the amount of a good that can be imported, both raise the price of agricultural imports.

In one of the early works on PPP, Cassel (1921) noted the effects of trade restrictions, stating, "If trade between two countries is more hampered in one direction than in the other, the value of the money of the country whose export is relatively more restricted will fall, in the other country, beneath the purchasing power parity." 9 Cassel emphasized the effect of export restrictions on PPP because these restrictions were used extensively during 
World War I. He noted, however, that import restrictions have the opposite effect. Thus, given two countries, the one with the greater restrictions on imports will see its currency overvalued on a PPP basis. If there were no other factors causing deviations from PPP, the Big Mac data would tell us which countries had high agricultural barriers to trade relative to the United States. That is, countries with high barriers to trade relative to the United States would have overvalued currencies relative to the dollar, whereas those with lower trade barriers than the United States would have undervalued currencies.

Trade barriers may partly explain why the Korean won has been consistently overvalued relative to the dollar on a PPP basis. Korea maintains high barriers to the importation of beef, the key ingredient of a Big Mac. From 1989 through 1994 Korea imposed a 30 percent tariff on beef imports in addition to imposing quantitative restrictions. In 1995 Korea eliminated quantitative restrictions on beef imports but raised the tariff to 44.1 percent. These trade barriers place a significant wedge between the price of beef in world markets and the domestic (Korean market) price of beef. Thus they could explain sustained deviations from PPP.

One additional factor that may help explain the deviations from PPP is tax differences across countries. The Big Mac prices reported by The Economist are inclusive of taxes. Thus, holding all other factors constant, countries with higher taxes on a Big M ac relative to the United States would appear to have overvalued currencies relative to the dollar. Changes in tax rates can also give rise to apparent revaluations of Big Mac parities. For example, in 1991 Canada imposed the Goods and Services Tax, a national 7 percent sales tax. Between 1990 and 1991, the price of a Big Mac rose from C $\$ 2.19$ to $C \$ 2.35$. As a result, the Canadian dollar moved from being undervalued by 14 percent against the U.S. dollar to being undervalued by only 9 percent. It would be misleading, however, to say that the United States and Canada were brought closer to PPP by the imposition of this new tax.

\section{Non-traded Goods}

According to the theory of PPP, if there are no barriers to trade, then the dollar price of a good should be the same in the United States, Hungary, and Japan. The price of a Big Mac in any country, however, reflects more than the price of its ingredients. To sell its products, M cDonald's has to buy or lease space for a restaurant and purchase utilities to heat, cool, and light the restaurant, as well as to run everything from the grills to the cash registers. Real estate and utilities are non-traded goods. Though the title to a piece of property, for example, can be traded, the location of the property cannot be traded. Thus although it may be cheaper to rent space for a restaurant in Budapest than in St. Louis, it is useless to do so if one wants to serve customers lunch in St. Louis. To the extent that rent and utilities determine the cost of a Big Mac, deviations from PPP may simply reflect these cost differences across countries.

The price of a Big Mac also reflects a service component- that is, the cost of preparing the Big Mac and serving the customer. These aspects require the use of workers, who in economic terminology are also non-traded goods. M CDonald's workers, like all workers, are restricted in their ability to move across borders to take advantage of wage differentials.

Balassa (1964) and Samuelson (1964) formalized the idea that non-traded goods systematically affect the deviation from PPP. They argued that because non-tradables are included in price indexes (such as the Big Mac index), high-income countries will have overvalued currencies relative to lowincome countries. This result is caused by differences in productivity across countries and sectors. The Balassa-Samuelson argument is based on the idea, supported empirically, that per capita income levels broadly reflect differences in labor productivity. ${ }^{10}$ Thus high-income countries have more productive labor forces than low-

\footnotetext{
${ }^{10}$ Kravis and Lipsey (1987 and 1988) have presented empirical evidence on the role of nontraded goods in differences in national price levels.
} 


\section{Figure 4}

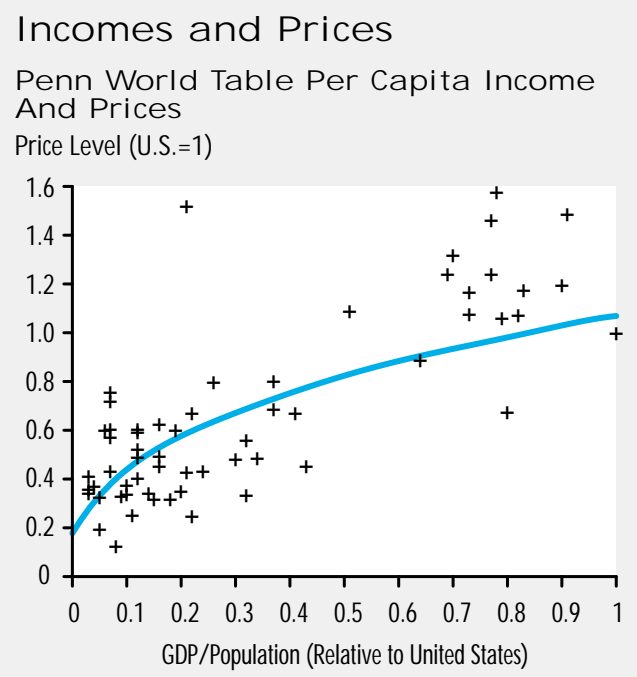

Average Earnings and Big Mac Prices Big Mac Price (\$)

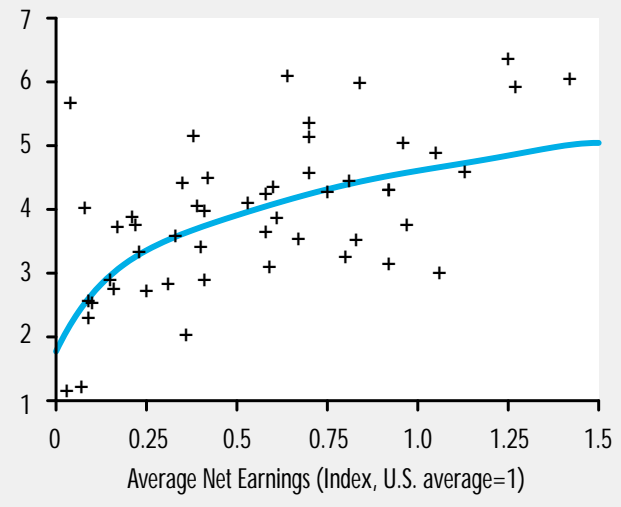

income countries. Furthermore, the differences in productivity are greatest in the traded goods sector. The higher productivity in traded goods in high-income countries is reflected in higher wages in all sectors and thus higher prices in the nontradable goods sector in these countries relative to low-income countries. ${ }^{11}$ The higher prices for non-tradable goods translates into higher price levels in high-income countries. Thus the currencies of these countries will appear overvalued relative to the currencies of low-income countries.

Turning to Big Macs, it is unlikely that there are large differences in the productivity of workers cooking burgers regardless of whether they are working in China or the United States. There are, how ever, large differences in the wages earned by these workers. For example, when McDonald's opened in China in 1992, the average monthly pay for a full-time starting worker was $\$ 60.12 \mathrm{~A}$ full-time starting worker at a McDonald's in the United States would earn a minimum of $\$ 737$ a month. ${ }^{13}$ This difference in wage costs may partly explain why the yuan has been consistently undervalued against the dollar as measured by Big Mac prices.

In fact, according to the BalassaSamuelson theory, holding all other things constant, the dollar should be overvalued against the currencies of developing countries. As illustrated in Table 2, the currencies of developing countries and the countries in transition (the former Communist countries) have generally been undervalued relative to the U.S. dollar. Of the 15 developing country currencies in the sample, there are only two that have been consistently and significantly overvalued: the Argentine peso and the South Korean won. ${ }^{14}$ The Big $\mathrm{Mac}$ index indicated that the Mexican peso was only slightly overvalued in 1994 but became significantly undervalued in $1995 .{ }^{15}$ With respect to the four transition economies included in the sample, the currencies of the Czech Republic, Hungary, and Poland have all been consistently undervalued relative to the U.S. dollar and the Russian ruble has been undervalued since 1992.

In contrast, the currencies of other industrial countries are generally overvalued relative to the U.S. dollar, consistently so against 13 of the 18 developed countries listed in Table 2. The British pound has been overvalued in all years except 1988. There are only three industrial countries against whose currencies have shown consistent evidence of undervaluation: the two antipodean countries (Australia and $\mathrm{N} \mathrm{ew}$ Zealand) and Canada.

More generally, we would expect to see a positive relationship between price levels and per capita income when comparing countries. Figure 4 plots two measures of this relationship. The upper panel uses the data from the PWT data set for 1990 to compare PPP price levels with 


\section{Table 2}

\section{Currency Valuation}

\section{Industrial Countries}

\begin{tabular}{l|c|}
\hline Country & Data Period \\
\hline Australia & $1986,1988-95$ \\
\hline Austria & $1994-95$ \\
Belgium & $1986-95$ \\
Britian & $1986-95$ \\
Canada & $1986,1988-95$ \\
Denmark & $1987-95$ \\
France & $1986-95$ \\
Germany & $1986-95$ \\
Greece & 1994 \\
Ireland & $1986-93$ \\
Italy & $1987-95$ \\
Japan & $1986,1988-95$ \\
Netherlands & $1986-95$ \\
New Zealand & 1995 \\
Portugal & 1994 \\
Spain & $1986,1988-95$ \\
Sweden & $1986,1988-95$ \\
Switzerland & $1993-95$ \\
&
\end{tabular}

\section{Undervaluation or Overvaluation} of Local Currency

Under

Over

Over

Over, Under (88)

Under, Over (92)
Over
Over
Over
Over

Parity $(86,91,93)$, Under $(88-90)$, Over $(87,92)$
Over
Over
Over
Under
Over
Over
Over
Over

\section{Developing Countries and Countries in Transition}

\section{Country}

Argentina

Brazil

Chile

China

Czech Republic

Hong Kong

Hungary

Indonesia

Israel

Malaysia

Mexico

Poland

Russia

Singapore

South Korea

Taiwan

Thailand

Venezuela

Yugoslavia
Data Period

1992-95

1992-95

1994-95

1992-95

1994-95

1986,1988-95

1991-95

1995

1995

1993-95

1993-95

1994-95

1990-95

1986,1988-92,1994-95

1989-95

1994-95

1993-95

1992

1988-91
Undervaluation or Overvaluation of Local Currency

Over
Under $(92,94)$, Over $(93,95)$
Parity $(94)$, Over $(95)$
Under
Under
Under
Under
Under
Over
Under
Parity (93), Over( 94$),$ Under (95)
Under
Under, Over (90-91)
Under, Over (92)
Over
Over
Under
Over
Under


${ }^{16}$ The data used in the lower panel of Figure 4 come from the Union Bank of Switzerland's (UBS) 1994 edition of "Prices and Earnings Around the Globe." The UBS prices are based on a Big Mac or similar hamburger price and include a large order of french fries.

${ }^{17}$ One exception may be the dollarl yen exchange rate. Marston (1987) finds that deviations from PPP in the dollar/ yen exchange rate appear to be related to a relatively high growth rate of productivity in the Japanese traded-goods sector.

${ }^{18}$ Examples of studies that illustrate the failure of the law of one price include Ceglowski (1994) and Giovannini (1988). Engel and Rogers (1995) study the law of one price both within and across countries. They argue that distance between cities is the primary factor responsible for price deviations within a country but not across countries. Specifically, two nearby cities that are separated by an international border will exhibit much greater disparity in goods prices than two comparably distant cities not separated by an international border.

${ }^{19}$ Feenstra and Kendall (1994) find that incomplete passthrough is a significant source of deviations from PPP in the post-1973 period

${ }^{20}$ See, for example, Krugman (1987). gross domestic product [ reproduced and updated from Summers and Heston (1991)] The lower panel presents a similar comparison, plotting the hamburger prices against average net earnings for cities around the world. ${ }^{16}$ As we might expect from a bundle of goods that includes both tradable and non-tradable components, the relationship between Big Mac prices and incomes closely parallels the relationship that exists for more inclusive measures of the overall price level.

W hile the Balassa-Samuelson theory may be useful in explaining deviations from PPP between developed and developing countries, it is less useful in explaining differences across countries with more similar per capita incomes. Thus we would hesitate to argue that the undervaluation of the dollar against the currencies of most other developed countries is reflective of more productive labor forces in these countries relative to the United States. ${ }^{17}$

\section{Imperfect Competition}

The inclusion of non-traded goods in price indexes is often considered the primary explanation for deviations from PPP. This is because in the absence of trade barriers, which for most goods are not substantial, the law of one price states that the price of tradable goods will be the same in all countries. In recent years, however, economists have modified their thinking on the equalization of tradable goods prices. Borrowing from models of price discrimination, some economists have argued that, in the presence of imperfect competition, traded goods prices may not be equal across countries. Such inequalities will result in deviations from PPP. Some economists have argued that differences in tradable goods prices account for much of the deviation from PPP. 18

Differences in traded goods prices across countries can occur if firms are able to price to market- that is, charge different prices in different countries. Price discrimination theory states that a firm will maximize profits by varying prices in accordance with the elasticity of demand for a product. The elasticity of demand indicates how the quantity demanded of a product changes given a change in price. If the price of a good increases by 10 percent and the quantity demanded falls by less than 10 percent, the demand for this product is said to be inelastic. If the price increases by 10 percent and the quantity demanded falls by more than 10 percent, the demand for this product is elastic. Sales revenue rises following an increase in the price of a good whose demand is inelastic and falls following an increase in the price of a product whose demand is elastic. A pricediscriminating firm would be able to maximize revenue by charging a higher price for its product in a country where demand is inelastic relative to a country where demand is more elastic.

One way in which firms price to market in international markets is by limiting exchange rate pass-through. Exchange rate pass-through indicates what percent of a change in the exchange rate is passed through to import prices. If exchange rate pass-through is complete, any change in exchange rates will be reflected in the local prices of imported goods. Thus if exchange rate pass-through was complete, the 90 percent fall in the M exican peso against the dollar between 1994 and 1995 should have been reflected in a 90 percent decline in the price of M exican sesame seeds sold in the United States. Incomplete exchange rate pass-through means that the price of imported goods does not fall (rise) by as much as the fall (rise) in the value of the foreign currency. If exchange rate pass-through is incomplete, then a wedge occurs between the prices of the good in the domestic and foreign markets. ${ }^{19}$

The ability of a firm to price to market depends on the ease with which goods can be resold across countries. For example, because of differences in safety and pollution standards, as well as warranty restrictions, it is difficult for individuals to resell automobiles across borders. The automobile market is one of the more commonly cited examples of pricingto-market behavior. ${ }^{20}$

Clearly the Big Mac cannot be easily resold across borders. However, all of its 
components are easily resold. Thus it would be fairly easy for someone to purchase the ingredients necessary to create a Big Mac and sell a competing sandwich. Though in some markets, most notably the United States, the Big Mac has close substitutes, in many countries the Big Mac has few substitutes. Perhaps this is because a Big $M$ ac is more than the sum of its ingredients. In Russia, for example, the price of a meal at a M CDonald's is costly relative to other restaurants. However, the quality of the food is considered far superior to that offered in most other restaurants frequented by the average Russian. In addition, the food itself is only part of the attraction. People choose to frequent $M c D$ onald's for more than the burgers, and these factors may be reflected in price differences across borders. The courteous, efficient service attracts many patrons, as does the cleanliness of the restaurant. At the opening of the first McDonald's in China, many patrons "commented on the novelty of restaurant employees who are enthusiastic rather than surly."21 Even in the United States, where there is a plethora of M cDonald's-type restaurants, the availability of Playlands (areas with playground equipment for children) at many M cDonald's makes the restaurant more attractive than its competitors to parents of young children.

Looking at the data for Big Mac prices in Japan and in the United States, we can find some evidence that might be interpreted as supportive of pricing-to-market behavior. Between 1993 and 1995 the dollar fell by 25 percent against the yen. Because McDonald's in Japan imports the beef-the most costly ingredient that goes into the Big $\mathrm{Mac}-\mathrm{a}$ decline in the value of the dollar should have reduced the yen price of a Big Mac. Figure 5 compares the actual yen price of the Big Mac with a hypothetical price path that takes account of exchange rate changes since 1988. Although the yen price of a Big Mac rose slightly after the dollar appreciated during the late 1980s, it has remained constant at 391 yen during the sharp decline of the dollar during the 1990s. Thus there is little evidence of pass-through.

On the other hand, in October 1995

\section{Figure 5}

Big Mac Prices in Japan

Japanese Yen

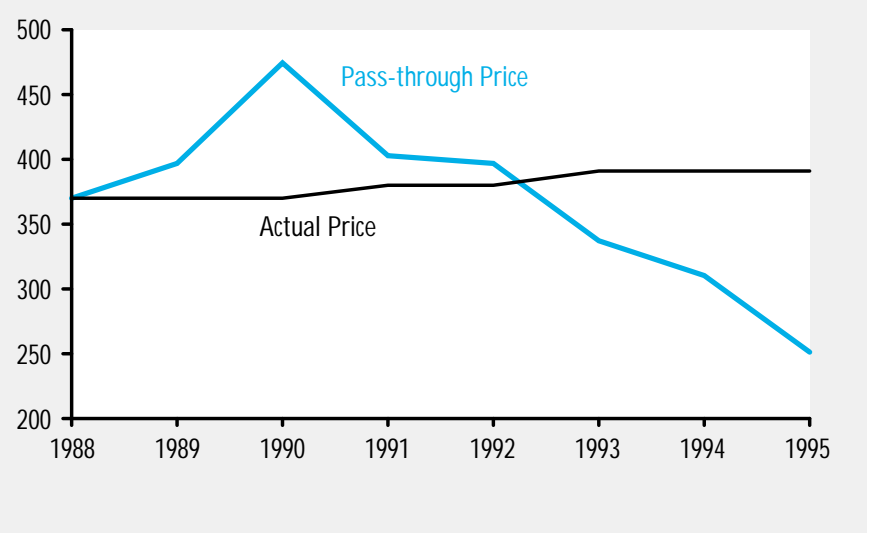

McDonald's Co. (Japan) Ltd. announced that it was lowering the price of a Big $M$ ac by more than 100 yen, a reduction of more than 25 percent. ${ }^{22}$ This brought the price of a Big Mac roughly in line with the exchange rate change over the past three years. However, though the price change reduced the overvaluation of the yen as calculated using the Big M ac index, it did not completely eliminate this overvaluation. The new PPP level of the exchange rate, approximately 120 yen/dollar, was still above the actual yen/dollar exchange rate.

\section{Current A ccount Imbalances}

Another reason that exchange rateadjusted prices might differ across countries is that exchange rates reflect international trade not only in goods and services, but also in financial assets. The PPP-based approach to evaluating exchange rates only considers the role of international commodity trade; however, trade in assets is arguably just as important (if not more important) in determining supply and demand for currencies. Cross-country asset flows are, in turn, closely related to positions of trade balance and imbalance among nations.

The broadest measure of a country's trade position is the current account, which measures international flows of goods,

\footnotetext{
${ }^{21}$ Kristof (1992).

22 The Economist, October 21 1995, p. 77.
} 
Big Mac-based PPPs and Current Account Balances

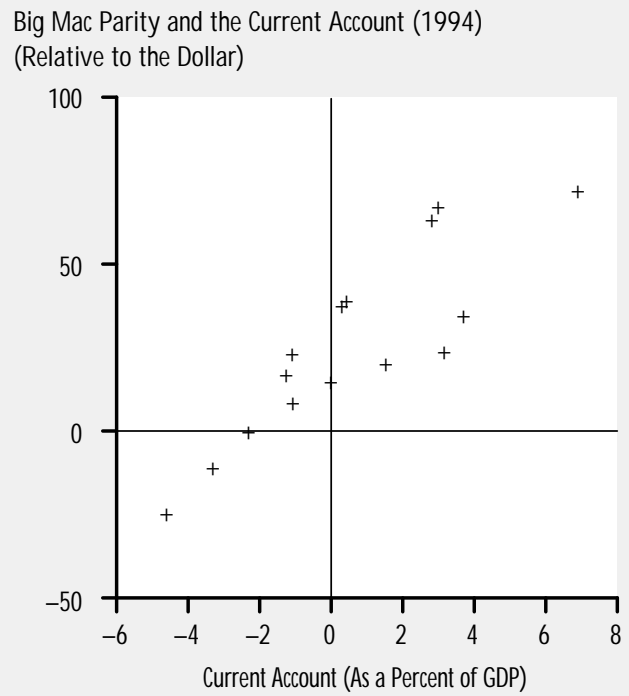

services, investment income, and unilateral transfers. On a fundamental level, a country that has a current account deficit is attracting capital from the rest of the world. That is, a country that is purchasing more abroad than it is selling abroad must finance the difference by borrowing. Similarly, a country with a current account surplusthat is, a country exporting more goods and services than it is importing-will necessarily be investing abroad. ${ }^{23}$

Current account imbalances can therefore be thought of as reflecting discrepancies between domestic investment
${ }^{23}$ The relationship between capital flows and current account balances is reflected in the notion of a country's capital account, which measures inflows and outflows of assets. As an accounting identity, a current account deficit is offset by a capital account surplus.

${ }^{24}$ See, for example, Rose (1991).

25 The Economist, August 26, 1995. Figure 6 contains only industrial countries to abstract from PPP differences caused by the Balassa-Samuelson effect. and savings. As these imbalances generate demand and supply changes for assets denominated in various currencies, exchange rates might deviate significantly from PPP. Various theories of the relationship between the current account and exchange rate movements predict different relationships between these two variables. In fact, researchers have generally failed to find a significant relationship- either positive or negative- between the two. ${ }^{24}$

In a recent issue of The Economist, a chart like that shown in the left panel of Figure 6 was used to illustrate a supposedly strong positive relationship between Big Mac-based PPPs and current account
Big Mac Parity and the Current Account (1992) (Relative to the Dollar)

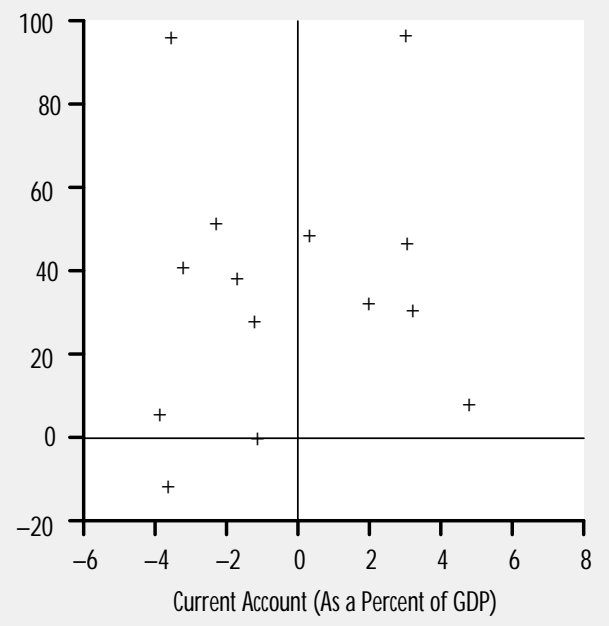

balances. ${ }^{25}$ Using 1994 data, each of the countries whose currencies are overvalued relative to the dollar have current account surpluses or smaller deficits than the United States. Similarly, the two countries that have undervalued currencies each have larger current account deficits than the United States.

However, this relationship does not hold generally. The right panel of Figure 6 shows the same comparison for 1992, with no apparent relationship between Big Mac PPPs and current account balances. In particular, the majority of countries with larger deficits than the U.S. deficit appear to have currencies that were overvalued relative to the dollar in 1992. Although current account surpluses and deficits can conceivably cause exchange rates to deviate from their PPP values, it is difficult to conclude much about the direction or magnitude of the effect.

\section{CONCLUSION}

Although the theory of PPP serves as a useful benchmark for thinking about longterm equilibrium in foreign exchange markets, it generally does poorly as a pre- 


\section{REVIEW}

JANUARY/ FEBRUARY 1996

dictive tool. A great deal of research effort has been put into tests of PPP and in constructing price measures for consistent bundles of commodities across countries. It is interesting to find that the simple collection of items comprising the Big Mac sandwich does just as well (or just as poorly) at demonstrating the principles and pitfalls of PPP as do more sophisticated measures.

This is perhaps not surprising when we consider that the Big M ac is a composite of tradable commodities and non-tradable service content. Its ingredients are subject to various tariffs and nontariff trade barriers in countries around the world. Finally, though it may have close rivals in some markets, the Big Mac itself is produced by only one company; hence we might expect to find elements of imperfect competition.

That many of its basic ingredients are tradable goods would lead us to believe that Big Mac prices around the world should be driven to equality by arbitrage. Its other characteristics make the Big M ac a good example of why the theory of PPP generally fails to hold except under special circumstances.

\section{REFERENCES}

Balassa, Bela. "The Purchasing-Power Parity Doctrine: A Reappraisal," Journal of Political Economy (December 1964), pp. 584-96.

Cassel, Gustav. The World's Monetary Problems. Constable and Company, Ltd., 1921.

Ceglowski, Janet. "The Law of One Price Revisited: New Evidence on the Behavior of International Prices," Economic Inquiry (July 1994), pp. 407-18.

Cumby, Robert E. "Forecasting Exchange Rates and Relative Prices With the Hamburger Standard: Is What You Want What You Get With McParity?" Manuscript. Georgetown University, July 1995

Curtius, Mary. "Billions Served- But Not Orthodox Jews of Jerusalem," Los Angeles Times, May 20, 1995

Driver, Nick. "A Cultural Revolution in Beijing, via Golden Arches," Los Angeles Times, April 23, 1992.

Engel, Charles, and John H. Rogers. "How Wide is the Border?" Board of Govemors of the Federal Reserve System, International Finance Discussion Papers, No. 498, February 1995.

Feenstra, Robert $C_{\text {, }}$ and I on D. Kendall. "Pass-Through of Exchange Rates and Purchasing Power Parity," National Bureau of Economic Research Working Paper, No. 4842, August 1994.
Giovannini, Alberto. "Exchange Rates and Traded Goods Prices," Journal of International Economics (February 1988), pp. 45-68.

Kravis, Irving B., and Robert E. Lipsey. "National Price Levels and the Prices of Tradables and Nontradables," The American Economic Review (May 1988), pp. 474-78.

_. _. _ _ and _. _. _. "The Assessment of National Price Levels," in Sven W. Arndt and J. David Richardson, eds., Real-Financial Linkages among Open Economies. MIT Press, 1987, pp. 97-134.

Kristof, Nicholas D. "Billions Served (and That Was Without China)," The New York Times, April 23, 1992.

Krugman, Paul R. "Pricing to Market when the Exchange Rate Changes," in Sven W. Amdt and J. David Richardson, eds., Real-Financial Linkages among Open Economies. MIT Press, 1987, pp. 49-70.

Marston, Richard C. "Real Exchange Rates and Productivity Growth in the United States and Japan," in Sven W. Arndt and J. David Richardson, eds., Real-Financial Linkages among Open Economies. MIT Press, 1987, pp. 71-96.

Rogoff, Kenneth. "What Remains of Purchasing Power Parity?" Federal Reserve System Board of Governors Working Paper, No. 2114, March 1995.

Rose, Andrew K. "The Role of Exchange Rates in a Popular Model of International Trade: Does the 'Marshall-Lerner' Condition Hold?" Journal of Intemational Economics (May 1991), pp. 301-16.

Samuelson, Paul A. "Theoretical Notes on Trade Problems," Review of Economics and Statistics (May 1964), pp. 145-64.

Sapsford, Jathon. "Is the Big Mac a Mere Cheeseburger Or a Benchmark for Currencies?" The Wall Street Journal, March 13, 1993.

Summers, Robert, and Alan Heston. "The Penn World Table (Mark 5): An Expanded Set of International Comparisons, 1950-1988," The Quarterly Journal of Economics (May 1991), pp. 327-68.

The Economist, various issues, 1986-1995.

Union Bank of Switzerland. Prices and Eamings Around the Globe: 1994 Edition. Union Bank of Switzerland, 1994.

Wei, Shang-Jin, and David C. Parsley. "Purchasing Power Dis-Parity During the Floating Rate Period: Exchange Rate Volatility, Trade Barriers and other Culprits." Federal Reserve System Board of Governors Working Paper, No. 2141, 1995. 


\section{PURCHASING POWER PARITY}

\section{TABLE A1}

Table A1 reports measures of Big Mac PPP against the U.S. dollar for all of the countries surveyed by The Economist over the years. The numbers are constructed as $[(1 / e) \times(P * / P \$)] \times 100$. A value greater than 100 means that dollar-equivalent prices in the country under consideration are higher than prices in the United States.

For example, in 1995 it cost $\$ 2.32$ to buy a Big Mac in the United States and $\$ 3.54$ to buy a Big Mac in Sweden (after conversion to dollars using the dollar/krona exchange rate). These prices indicate that in terms of its purchasing power, the dollar was worth 53 percent more (had a higher value) in the United States than in Sweden. Thus, relative to its PPP level, the dollar was undervalued against the Swedish krona and the krona was overvalued against the dollar. In 1995 it cost $\$ 1.58$ to buy a Big Mac in Hungary, a mere 68 percent of the U.S. price. In this case, the purchasing power of the U.S. dollar was greater in Hungary than in the United States. Thus, relative to its PPP level, the dollar was overvalued against the Hungarian forint and the forint was undervalued against the U.S. dollar.

\section{TABLE A2}

The data in Table A2 are intended to be suggestive of whether relative PPP holds for Big Mac prices. For each country there are two rows of data. The first row, inflation differential, presents data corresponding to the right side of equation 3 (p.8). For our purpose, the inflation differential is the difference in price changes for the Big Mac between each country listed and the United States. The next row, change in exchange rate, presents data corresponding to the left side of equation 3 . For example, in 1992 it cost 108 francs to buy a Big Mac in Belgium. The price increased to 109 francs in 1993, showing a 0.92 percent rate of inflation. In the
United States it cost $\$ 2.19$ to buy a Big Mac in 1992 and \$2.28 in 1993. Big Mac inflation was 4.03 percent in the United States over this period. Big Mac prices rose by 3.11 percent less in Belgium than in the United States. Thus the inflation differential was -3.11 percent. The Bel gian franc/U.S. dollar exchange rate was 33.55 in 1992 and 32.45 in 1993. The change in the exchange rate was -3.33 percent. Because the exchange rate change was approximately equal to the inflation differential, we can conclude that relative PPP held for the Belgian franc/U.S. dollar exchange rate during this period. This is reflected in the 1993 column in Table A2.

The Big $M$ ac data indicate that relative PPP generally did not hold on a year-toyear basis. This is not surprising given the myriad factors that can influence the exchange rate in the short run. The last column in Table A2 presents a simple test of relative PPP using the Big Mac data over a longer time. This column calculates the cumulative change in the exchange rate and Big Mac inflation differentials for each country relative to the dollar. Using this measure, relative PPP held for the Hungarian forint and I rish punt relative to the dollar. For all other currencies, even over a longer period, relative PPP fails to hold. Furthermore, for many countries, contrary to what theory predicts, the exchange rate changes and the inflation differentials moved in opposite directions. For example, Big Mac inflation was 6 percent less in Italy than in the United States over the period 1987-95. If relative PPP held, the Italian lira should have appreciated by 6 percent against the U.S. dollar during this period. In actuality, the lira depreciated by 24 percent against the dollar. Thus there was a 30 percent real depreciation of the lira against the dollar. 


\section{Table A1}

\section{Purchasing Power Parity}

$\begin{array}{llllllllll}1986 & 1987 & 1988 & 1989 & 1990 & 1991 & 1992 & 1993 & 1994 & 1995\end{array}$

\begin{tabular}{|c|c|c|c|c|c|c|c|c|c|c|}
\hline Argentina & $N A^{*}$ & NA & NA & NA & NA & NA & 152 & 158 & 157 & 129 \\
\hline Australia & 67 & NA & 60 & 84 & 79 & 86 & 89 & 77 & 75 & 78 \\
\hline Austria & NA & NA & NA & NA & NA & NA & NA & NA & 123 & 173 \\
\hline Belgium & 134 & 144 & 108 & 113 & 127 & 129 & 147 & 147 & 135 & 165 \\
\hline Brazil & $\mathrm{NA}$ & NA & NA & $N A$ & NA & NA & 81 & 123 & 69 & 116 \\
\hline Britain & 103 & 104 & 92 & 106 & 104 & 133 & 139 & 122 & 116 & 121 \\
\hline Canada & 85 & NA & 69 & 89 & 86 & 91 & 106 & 96 & 89 & 86 \\
\hline Chile & NA & NA & NA & NA & NA & NA & NA & NA & 100 & 104 \\
\hline China & NA & NA & NA & NA & NA & NA & 53 & 66 & 45 & 45 \\
\hline Czech. Rep. & NA & NA & NA & NA & NA & NA & NA & NA & 73 & 82 \\
\hline Denmark & NA & 187 & 150 & 167 & 181 & 185 & 197 & 186 & 167 & 212 \\
\hline France & 154 & 173 & 129 & 138 & 143 & 142 & 149 & 152 & 138 & 166 \\
\hline Germany & 131 & 136 & 103 & 113 & 116 & 114 & 125 & 128 & 117 & 150 \\
\hline Greece & $\mathrm{NA}$ & NA & NA & NA & NA & NA & NA & NA & 107 & NA \\
\hline Hong Kong & 61 & NA & 41 & 48 & 50 & 51 & 53 & 51 & 52 & 53 \\
\hline Hungary & NA & NA & NA & NA & NA & 68 & 76 & 78 & 71 & 68 \\
\hline Indonesia & NA & NA & NA & NA & NA & NA & NA & NA & NA & 75 \\
\hline Ireland & 100 & 106 & 82 & 91 & 94 & 100 & 109 & 100 & NA & NA \\
\hline |srael & $N A$ & NA & NA & NA & NA & NA & NA & NA & NA & 130 \\
\hline Italy & NA & 154 & 112 & 118 & 144 & 129 & 152 & 130 & 121 & 114 \\
\hline | apan & 150 & NA & 125 & 138 & 106 & 125 & 130 & 152 & 163 & 200 \\
\hline Malaysia & $N A$ & NA & NA & NA & NA & NA & NA & 57 & 61 & 65 \\
\hline Mexico & NA & NA & NA & NA & NA & NA & NA & 100 & 105 & 74 \\
\hline Netherlands & 119 & 132 & 109 & 119 & 127 & 124 & 133 & 135 & 124 & 152 \\
\hline New Zealand & NA & NA & NA & NA & NA & NA & NA & NA & NA & 84 \\
\hline Poland & NA & NA & NA & NA & NA & NA & NA & NA & 60 & 63 \\
\hline Portugal & NA & NA & NA & NA & NA & NA & NA & NA & 110 & NA \\
\hline Russia & NA & NA & NA & NA & 284 & 255 & 27 & 50 & 71 & 70 \\
\hline Singapore & 81 & NA & 59 & 71 & 63 & 70 & 131 & NA & 83 & 91 \\
\hline Spain & 122 & NA & 107 & 118 & 127 & 151 & 141 & 125 & 109 & 123 \\
\hline Sweden & 150 & NA & 131 & 162 & 179 & 191 & 196 & 151 & 139 & 153 \\
\hline Switzerland & NA & NA & NA & NA & NA & NA & NA & 172 & 172 & 225 \\
\hline S. Korea & NA & NA & NA & 178 & 135 & 129 & 135 & 127 & 123 & 129 \\
\hline Taiwan & NA & NA & NA & NA & NA & NA & NA & NA & 102 & 109 \\
\hline Thailand & NA & NA & NA & NA & NA & NA & NA & 84 & 82 & 84 \\
\hline Venezuela & NA & NA & NA & NA & NA & NA & 128 & NA & NA & \\
\hline Yugoslavia & NA & NA & 69 & 38 & 62 & 94 & NA & NA & NA & \\
\hline
\end{tabular}

* NA indicates data are not avalable.

Note: A number less than 100 indicates that the local currency is undervalued relative to the U.S. dollar on a PPP basis.

A number greater than 100 indicates that the local currency is overvalued relative to the U.S. dollar on a PPP basis. 


\section{Table A2}

\section{Relative Big Mac Purchasing Power Parity}

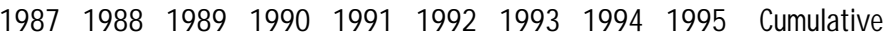

\section{Argentina}

Inflation differential

Change in exchange rate

Australia

Inflation differential

Change in exchange rate

Austria

Inflation differential

Change in exchange rate

Belgium

Inflation differential

Change in exchange rate

Brazil

Inflation differential

Change in exchange rate

Britian

Inflation differential

Change in exchange rate

Canada

Inflation differential

Change in exchange rate

Chile

Inflation differential

Change in exchange rate

\section{China}

Inflation differential

Change in exchange rate

Czech Republic

Inflation differential

Change in exchange rate

Denmark

Inflation differential

Change in exchange rate

France

Inflation differential

Change in exchange rate

Germany

Inflation differential

Change in exchange rate

\section{Hong Kong}

Inflation differential

Change in exchange rate

\section{Hungary}

Inflation differential

Change in exchange rate

Ireland

Inflation differential

Change in exchange rate

\begin{tabular}{|c|c|c|c|c|c|c|c|c|c|}
\hline$N A^{*}$ & NA & NA & NA & NA & NA & $5 \%$ & $-1 \%$ & $-19 \%$ & $-15 \%$ \\
\hline NA & NA & NA & NA & NA & NA & $1 \%$ & $0 \%$ & $0 \%$ & $1 \%$ \\
\hline NA & NA & $24 \%$ & $1 \%$ & $4 \%$ & $6 \%$ & $-8 \%$ & $-1 \%$ & $-1 \%$ & $26 \%$ \\
\hline NA & NA & $-9 \%$ & $6 \%$ & $-4 \%$ & $3 \%$ & $6 \%$ & $2 \%$ & $-5 \%$ & $-1 \%$ \\
\hline NA & NA & NA & NA & NA & NA & NA & NA & $13 \%$ & $13 \%$ \\
\hline NA & NA & NA & NA & NA & NA & NA & NA & $-21 \%$ & $-21 \%$ \\
\hline $\begin{array}{r}0 \% \\
-7 \%\end{array}$ & $-40 \%$ & $17 \%$ & $-1 \%$ & $1 \%$ & $10 \%$ & $-3 \%$ & $-1 \%$ & $-1 \%$ & $-18 \%$ \\
\hline & & & & $-0 \%$ & $-3 \%$ & $-3 \%$ & $8 \%$ & $-21 \%$ & $-39 \%$ \\
\hline NA & NA & NA & NA & NA & NA & \multirow{2}{*}{\multicolumn{3}{|c|}{$\begin{array}{l}297 \%-395 \%-644 \% \\
255 \%-337 \%-696 \%\end{array}$}} & $-742 \%$ \\
\hline NA & NA & NA & NA & NA & NA & & & & $-778 \%$ \\
\hline $3 \%$ & $-35 \%$ & $23 \%$ & $2 \%$ & $15 \%$ & $7 \%$ & $-1 \%$ & $0 \%$ & $-5 \%$ & $9 \%$ \\
\hline $1 \%$ & $-23 \%$ & $9 \%$ & $3 \%$ & $-9 \%$ & $2 \%$ & $12 \%$ & $7 \%$ & $-10 \%$ & -8 \\
\hline NA & NA & $22 \%$ & $-7 \%$ & $5 \%$ & $19 \%$ & $-4 \%$ & $3 \%$ & $-4 \%$ & $33 \%$ \\
\hline NA & NA & $-4 \%$ & $-3 \%$ & $-1 \%$ & $3 \%$ & $6 \%$ & $10 \%$ & $0 \%$ & $11 \%$ \\
\hline NA & NA & NA & NA & NA & NA & NA & NA & $-1 \%$ & $-1 \%$ \\
\hline NA & NA & NA & NA & NA & NA & NA & NA & $-5 \%$ & $-5 \%$ \\
\hline NA & NA & NA & NA & NA & NA & $26 \%$ & $5 \%$ & $-1 \%$ & $30 \%$ \\
\hline NA & NA & NA & NA & NA & NA & $4 \%$ & $43 \%$ & $-2 \%$ & $45 \%$ \\
\hline NA & NA & NA & NA & NA & NA & NA & NA & $-1 \%$ & $-1 \%$ \\
\hline NA & NA & NA & NA & NA & NA & NA & NA & $-13 \%$ & $-13 \%$ \\
\hline NA & $-34 \%$ & $25 \%$ & $-6 \%$ & $3 \%$ & $5 \%$ & $-10 \%$ & $-1 \%$ & $3 \%$ & $-15 \%$ \\
\hline NA & $-12 \%$ & $14 \%$ & $-14 \%$ & $0 \%$ & $-2 \%$ & $-4 \%$ & $10 \%$ & $-21 \%$ & $-28 \%$ \\
\hline $6 \%$ & $-41 \%$ & $19 \%$ & $-9 \%$ & $-1 \%$ & $3 \%$ & $-2 \%$ & $-1 \%$ & $-1 \%$ & $-25 \%$ \\
\hline$-5 \%$ & $-11 \%$ & $12 \%$ & $-12 \%$ & $0 \%$ & $-2 \%$ & $-4 \%$ & $9 \%$ & $-19 \%$ & $-33 \%$ \\
\hline$-4 \%$ & $-40 \%$ & $22 \%$ & $-9 \%$ & $-2 \%$ & $7 \%$ & $-2 \%$ & $-1 \%$ & $3 \%$ & $-25 \%$ \\
\hline$-7 \%$ & $-13 \%$ & $13 \%$ & $-12 \%$ & $-1 \%$ & $-2 \%$ & $-4 \%$ & $8 \%$ & $-21 \%$ & $-38 \%$ \\
\hline NA & NA & $17 \%$ & $4 \%$ & $1 \%$ & $3 \%$ & $-3 \%$ & $1 \%$ & $2 \%$ & $25 \%$ \\
\hline NA & NA & $-0 \%$ & $0 \%$ & $0 \%$ & $-1 \%$ & $0 \%$ & $0 \%$ & $0 \%$ & $-1 \%$ \\
\hline NA & NA & NA & NA & NA & $17 \%$ & $13 \%$ & $6 \%$ & $11 \%$ & $48 \%$ \\
\hline NA & $N A$ & NA & NA & NA & $6 \%$ & $10 \%$ & $16 \%$ & $16 \%$ & $48 \%$ \\
\hline $0 \%$ & $-37 \%$ & $23 \%$ & $-9 \%$ & $5 \%$ & $6 \%$ & $-2 \%$ & NA & NA & $-13 \%$ \\
\hline$-6 \%$ & $-12 \%$ & $14 \%$ & $-12 \%$ & $-2 \%$ & $-2 \%$ & $6 \%$ & NA & NA & $-13 \%$ \\
\hline
\end{tabular}

FEDERAL RESERVE BANK OF St. LoUIS 


\section{Table A2 (continued)}

\section{Relative Big Mac Purchasing Power Parity}

$\begin{array}{lllllllll}1987 & 1988 & 1989 & 1990 & 1991 & 1992 & 1993 & 1994 & 1995\end{array}$ Cumulative

Italy

Inflation differential

Change in exchange rate

Japan

Inflation differential

Change in exchange rate

Malaysia

Inflation differential

Change in exchange rate

Mexico

Inflation differential

Change in exchange rate

\section{Netherlands}

Inflation differential

Change in exchange rate

Poland

Inflation differential

Change in exchange rate

Russia

Inflation differential

Change in exchange rate

Singapore

Inflation differential

Change in exchange rate

\section{South Korea}

Inflation differential

Change in exchange rate

\section{Spain}

Inflation differential

Change in exchange rate

\section{Sweden}

Inflation differential

Change in exchange rate

\section{Switzerland}

Inflation differential

Change in exchange rate

Taiwan

Inflation differential

Change in exchange rate

Thailand

Inflation differential

Change in exchange rate

Yugoslavia

Inflation differential

Change in exchange rate

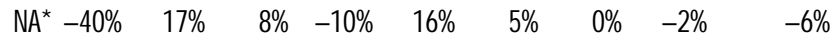

$$
\begin{aligned}
& \begin{array}{llllllllll}
\text { NA } & -9 \% & 12 \% & -12 \% & 1 \% & -0 \% & 21 \% & 7 \% & 4 \% & 24 \%
\end{array} \\
& \begin{array}{llllrrrrrr}
N A & N A & 17 \% & -9 \% & 0 \% & 3 \% & -1 \% & -1 \% & -1 \% & 8 \% \\
& N A & 7 \% & 18 \% & -16 \% & -1 \% & -16 \% & -8 \% & -21 \% & -39 \%
\end{array}
\end{aligned}
$$

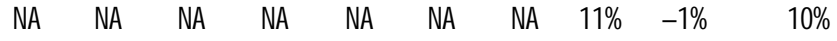

$$
\begin{aligned}
& \text { NA NA NA NA NA NA NA } 4 \% \text { - } 8 \% \text { } \\
& \text { NA NA NA NA NA NA NA } 12 \% \quad 29 \% \quad 41 \% \\
& \begin{array}{lllllll}
\text { NA NA NA NA NA NA NA } & 8 \% & 64 \% & 72 \%
\end{array} \\
& \begin{array}{llllllllll}
3 \% & -33 \% & 22 \% & -6 \% & -2 \% & 5 \% & -2 \% & -1 \% & -1 \% & -15 \%
\end{array} \\
& \begin{array}{llllllllll}
-7 \% & -14 \% & 14 \% & -12 \% & 0 \% & -2 \% & -4 \% & 8 \% & -21 \% & -39 \%
\end{array}
\end{aligned}
$$

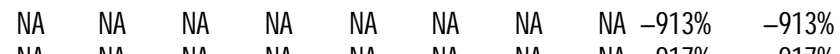

$$
\begin{aligned}
& \text { NA NA NA NA NA NA NA NA }-917 \%-917 \% \\
& \begin{array}{lllllllll}
\text { NA NA NA NA } & 96 \% & 178 \% & 256 \% & 130 \% & 102 \% & 762 \%
\end{array} \\
& \text { NA NA NA NA } 106 \% \quad 404 \% \quad 194 \% \quad 95 \% \quad 103 \% \quad 903 \% \\
& \text { NA NA } \quad 17 \%-16 \% \quad 5 \% \quad 56 \% \quad \text { NA } \quad \text { NA } \quad-2 \% \quad 60 \% \\
& \text { NA NA }-2 \% \quad-4 \% \quad-6 \% \quad-7 \% \quad \text { NA } \quad \text { NA }-11 \% \quad-31 \%
\end{aligned}
$$

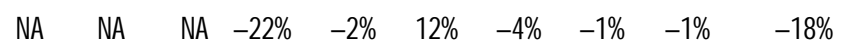

$$
\begin{aligned}
& \text { NA NA NA } 6 \% \quad 2 \% \quad 8 \% \quad 2 \% \quad 2 \% \quad-5 \% \quad 14 \%
\end{aligned}
$$

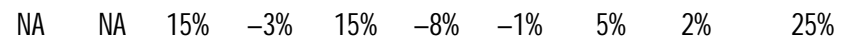

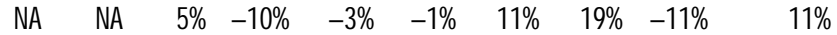

$$
\begin{aligned}
& \begin{array}{lllllllll}
\text { NA NA } & 29 \% & 5 \% & 6 \% & 1 \% & -4 \% & -1 \% & 1 \% & 37 \%
\end{array} \\
& \text { NA NA } \quad 8 \% \quad-5 \% \quad-1 \% \quad-2 \% \quad 23 \% \quad 7 \% \quad-8 \% \quad 22 \%
\end{aligned}
$$

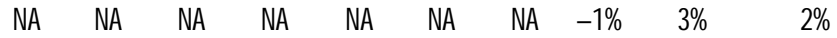

$$
\begin{aligned}
& \text { NA NA NA NA NA NA NA }-1 \% \text { - } 24 \% \quad-25 \%
\end{aligned}
$$

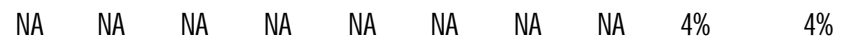

$$
\begin{aligned}
& \text { NA NA NA NA NA NA NA NA }-3 \% \quad-3 \%
\end{aligned}
$$

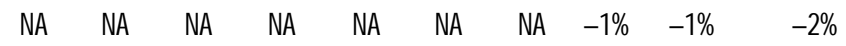

$$
\begin{aligned}
& \text { NA NA NA NA NA NA NA } 1 \% \quad-3 \% \quad-2 \% \\
& \begin{array}{lllllllll}
\text { NA } & \text { NA } & 128 \%-617 \% & 67 \% & \text { NA } & \text { NA } & \text { NA } & \text { NA } & -421 \% \\
\text { NA } & \text { NA } & 186 \%-664 \% & 25 \% & \text { NA } & \text { NA } & \text { NA } & \text { NA } & -453 \%
\end{array}
\end{aligned}
$$

* NA indicates data are not available. 
